\title{
Déjà Vu? An Updated Analysis of the Gender Wage Gap in the U.S. Hospitality Sector
}

Cornell Hospitality Quarterly

I-II

(C) The Author(s) 2015

Reprints and permissions:

sagepub.com/journalsPermissions.nav DOI: 10.1 I77//9389655|4567680 cqx.sagepub.com

(S)AGE

\author{
Susan S. Fleming'
}

\begin{abstract}
Drawing on a random sample of II2,990 people working in the U.S. hospitality sector in 2010, this study found strong evidence that there remains a significant difference in the income of women and men working in the industry, even after accounting for likely explanations such as differences in educational attainment and hours worked, as well as structural forms of discrimination such as occupational crowding. Across the entire hospitality industry, after controlling for these factors, being a woman was associated with a loss of income of $\$ 620$, relative to a mean income of $\$ 11,271$ per year. For the food service sector, being a woman cost $\$ 542$ relative to a mean income of $\$ 9,339$, and for the lodging sector, the gender penalty was $\$ 2,368$, compared with a mean income of $\$ 17,783$. However, managers faced the most severe penalties, as being a woman cost $\$ 6,617$ compared with a mean income of $\$ 30,577$ (21.6\%). This study echoed findings of a study that used 1989 data, which also found that women were paid substantially less than men across the entire industry. While the 2010 study data showed at least some progress toward wage equality, the wage difference remains noticeable despite the advancement of women in professional and executive positions in the United States in general, and specifically within the hospitality industry.
\end{abstract}

\section{Keywords}

gender wage gap; wage discrimination; bias against women

The more things change, the more they stay the same.

-Alphonse Karr

During the 1960s, 1970s, and 1980s, the United States saw dramatic increases in women's employment and rates of education, accompanied by changes in law that made many types of gender-based discrimination illegal and a shift in social attitudes about the acceptability of women working (Blau and Kahn 2007; England 2010). In parallel to this progress was a dramatic increase in the earnings of women relative to men. Based on the weekly earnings of full-time workers, the gender ratio (women's earnings divided by men's earnings) increased from 61.3 percent in 1978 to 76.8 percent in 1993 (Blau and Kahn 2007). As evidenced by these figures, notwithstanding the impressive progress that had been made, women were still paid significantly less than men.

Within the hospitality sector, similar changes occurred. The number of women in the industry's workforce increased, even among managerial positions (Umbreit and Diazy 1994). At the same time, though, the few studies investigating the wage gap suggested that women in hospitality were not paid comparably to men (Brownell 1994; Woods and
Kavanaugh 1994). Against this backdrop, Sparrowe and Iverson (1999) undertook a broad-based study of the gender wage gap in the hospitality industry, using 1989 U.S. census data. These authors controlled for the most commonly offered explanations for gender-based income disparity, including differences in education (human capital) (Becker 2009), hours worked (known as new home economics theory) (Becker 1965), and occupational crowding (a form of structural discrimination) (Bergmann 1974). Even after accounting for these factors, Sparrowe and Iverson found that women were paid substantially less than men across the entire hospitality industry sample, among managers in the industry, and specifically within the eating and drinking and hotel and motel sectors. In each case, the data suggested that wage discrimination was the only logical explanation for these differences. Although the authors were discouraged by their findings, they were hopeful that industry

'Cornell University, Ithaca, NY, USA

Corresponding Author:

Susan S. Fleming, School of Hotel Administration, Cornell University, 54IA Statler Hall, Ithaca, NY 14850, USA.

Email: sfc24@cornell.edu 
initiatives would gradually cure this differential. They thought this process might take decades "during which women move up through the ranks and higher paid men retire" (Sparrowe and Iverson 1999, 16). In this article, I present the results of a study that essentially replicates that of Sparrow and Iverson, with similar results - the pay gap still exists.

Certainly, much has changed since Sparrowe and Iverson's 1989 data were compiled. Twenty-five years later, we can document progress in many industries, including the hospitality sector. Though there are still no women CEOs among the thirteen hospitality companies included in the Fortune 500, women CEOs have led a number of smaller hospitality companies, including Four Seasons Hotels and Resorts, Sonesta Hotels, Carlson Hotels, Fairmont Hotels \& Resorts, Commune Hotels + Resorts, Buffalo Wild Wings, Cracker Barrel, and DineEquity (Boone et al. 2013). Furthermore, in 2012, women made up 14.4 percent of executive officers and 14.2 percent of corporate directors (Catalyst 2013a). Women also made up 45 percent of hospitality managers in 2007 (the last year for which data were reported) versus 54 percent of nonmanagerial staff (U.S. General Accountability Office 2010). Moreover, a number of industry organizations have for several years been dedicated to the advancement of women, including the Network of Executive Women in Hospitality (founded in 1984), Women Chefs \& Restaurateurs (1993), the Women's Foodservice Forum (1989), and the American Hotel \& Lodging Association Women in Lodging (2005). Moreover, several hospitality firms have also launched women's initiatives, including Marriott, Accor, Wyndham, and Carlson Hotels.

Given this progress and increased focus on the advancement of women in the last two decades, one would expect that the pay gap might have diminished. Few studies have examined this situation in the United States, although a number of studies on gender-based wage differences have been conducted in international settings in recent years (Campos-Soria, Ortega-Aguaza, and Ropero-Garcia 2009; Delfin and Varejao 2007; García-Pozo et al. 2012; Marchante, Ortega, and Pagan 2005; Muñoz-Bullón 2009; Skalpe 2007; Thrane 2008). Below, I discuss the single U.S.-based study that looked at the 2007 wage gap among hospitality managers (U.S. General Accountability Office 2010). First, however, let us review the supposed explanations for the gender wage gap, some of which I mentioned above.

\section{Theoretical Explanations for the Gender Wage Gap}

Theoretical explanations for gender-based differences in wages tend to fall into two broad categories: those offering "legitimate" reasons (i.e., justified by economic or other nondiscriminatory factors) for the disparity and those identifying discrimination as the explanation. Included in the first category are human capital theory (Becker 2009) and new home economics theory (Becker 1965). Human capital theory suggests that if individuals have varying levels of education, training, or experience, they will have varying productivity and thus varying pay levels. Similarly, the new home economics explanation proposes that people who choose to allocate different amounts of time to paid work will have varying levels of productivity, and thus, a corresponding difference in the wages they earn makes economic sense. Extending these arguments specifically to women, the argument is that if these individual differences in human capital or hours worked covary with gender, then one might observe a gender wage gap that is economically justified. The study I present here attempts to account for these explanatory factors, consistent with the procedure used by Sparrowe and Iverson.

The discrimination-related explanations include occupational overcrowding (Bergmann 1974), the devaluation of female work (England 1992), and social closure (Murphy 1988; Weber 1978). According to occupational crowding theory, wage rates are determined by the supply of available workers relative to the demand for such workers in a particular occupation. Furthermore, the theory suggests that men and women are sorted into occupations deemed appropriate based on gender stereotypes, and that the number of occupations open to women is smaller than the number of occupations open to men. The resulting oversupply of labor within occupations associated with women depresses wages for the occupations overall and for the disproportionately large number of female employees working in them (Bergmann 1974). Another explanation for the lower wages found in female occupations is that employers draw on gender stereotypes that devalue women's work, and as a result, set lower pay levels for both men and women working in female-dominated occupations (England 2010). Both of these theories are supported by a significant body of empirical research that demonstrates that the higher the proportion of women there are working within an industry or an occupation, the lower the wages are. In fact, occupation and industry category have been shown historically to be the greatest contributors to the gender wage gap (Blau and Kahn 2006; Boraas and Rodgers 2003; England 1992; Kilbourne et al. 1994)

Finally, social closure theory (Murphy 1988; Weber 1978) posits an alternative process of discrimination that can also result in wage inequality. According to this theory, higher status groups (such as white males) engage in exclusionary practices that reserve the best opportunities and jobs for members of the group, thus preserving their social and economic advantage over others. While research such as the study described herein cannot affirmatively demonstrate the presence of social closure practices (because the analysis may not include all factors contributing to a gender wage gap), finding that an unexplained wage gap persists 
after accounting for human capital differences, new home economics, and structural discrimination suggests that social closure practices may be operating.

\section{Current Studies on the U.S. Wage Gap}

If the wage gap has been largely eliminated across all industries in the United States or in the hospitality sector of other countries, we might expect to see a similar pattern in the U.S. hospitality sector. As I said, based on the weekly earnings of all U.S. full-time workers, the gender ratio was 76.8 percent in 1993, up from 61.3 percent in 1978 (Blau and Kahn 2007). As of 2012, the ratio was 80.9 percent, representing only modest progress since 1993 and an actual decline of more than one percentage point from 2011, when the ratio was 82.2 percent (Catalyst 2013c). This trend reflects considerably slowing progress (and now backsliding) in the closing of the gender earnings gap. While there was a dramatic closing of the gap in the 1980s and early 1990s, since 2001, the annual gender earnings gap has narrowed by only a single percentage point (Hegewisch, Williams, and Edwards 2013). A similar pattern can be found for management, professional, and related occupations, with women working full time in these jobs earning just 71.6 percent of the weekly wages earned by men in 2012. Furthermore, women continue to make less money than men across all educational levels, with the 2011 gender ratio ranging from a low of 74.3 percent for women holding master's degrees to a high of 79.1 percent for women holding doctoral degrees (Catalyst 2013c).

While the general U.S. wage gap data above provides a broad context to what we might expect specifically within the U.S. hospitality sector, it does have some limitations. First, while the data exclusively comprise full-time workers, they do not account for actual hours worked. Thus, these data may not account for new home economics theory, and women may in fact have allocated less time to paid work than men in the sample, thus resulting in a legitimate difference in wages. Furthermore, the data also do not account for possible human capital differences. Finally, these general U.S. wage gap data cover all full-time workers in all industries in the United States, but the study reported herein draws only from workers in the hospitality sector.

\section{Recent Studies on the Wage Gap in Hospitality}

Several international studies have addressed the gender wage gap in the hospitality sector (Campos-Soria, OrtegaAguaza, and Ropero-Garcia 2009; Delfin and Varejao 2007; García-Pozo et al. 2012; Marchante, Ortega, and Pagan 2005; Muñoz-Bullón 2009; Skalpe 2007; Thrane 2008). In addition, one recent study has investigated the wage gap in the U.S. hospitality industry; however, it addressed managers only (U.S. General Accountability Office 2010).

The following international studies found the presence of gender-based wage differences, even after accounting for "legitimate" explanations for such differences, thus suggesting some degree of implied sex discrimination.

\section{Norway}

Thrane (2008) found that men earned approximately 20 percent more than women based on an analysis of the wages of more than 100,000 employees working in the hospitality sector between 1994 and 2002. This study accounted for education, work experience, marital status, and number of children. Skalpe (2007) found a significant gender pay gap among CEOs of tourism firms, even after accounting for CEO age, firm size, firm performance, and whether the organization is located in an urban versus a rural setting.

\section{Spain}

García-Pozo et al. (2012) found the existence of a gender wage gap in each of the six tourism regions of Spain, once again controlling for job and personal characteristics such as firm size, type of employment contract, job tenure, experience, and formal education of the worker in relation to the job requirements. Based on a large matched employer-employee data set obtained from a broad group of tourism companies in Spain from 1998 through 2003, Muñoz-Bullón (2009) found that men earned 6.7 percent higher monthly wages than women working in the industry. However, all but 12 percent of this difference was explained by factors in the model, with type of contract, job type, and subsector accounting for most of the variance. In this case, the author controlled for firmspecific factors such as company size and the tourism sector in which they operate (e.g., hotels, restaurants, campsites), as well as individual characteristics such as age, job tenure, type of employment contract (e.g., interim, training, per-task, permanent), and job type (e.g., engineers, skilled clerks, semiskilled clerks, unskilled laborers). In sum, the author concluded that a wage gap does still exist, although the unexplained portion of the wage gap was smaller than that found in other industries, potentially due to Spain's strong minimum wage law, which provides a "particularly effective protection to women in the tourism industry, which is characterized by a large number of low-wage earners." This wage gap does, however, suggest some level of sex discrimination (Muñoz-Bullón 2009, 638).

\section{Portugal}

Finally, Delfin and Varejao (2007) found that women earned 8.4 percent less than men in the hospitality sector, of which approximately 55 percent remained unexplained after controls. 


\section{The United States}

The U.S. General Accountability Office study that I mentioned above was focused on the representation of women within middle management, and the relative wages of male and female managers within thirteen industry sectors of the United States in 2007. The data were drawn from the American Community Survey (ACS), which includes a broad survey of the U.S. population in conjunction with the U.S. Census. Consistent with Sparrowe and Iverson's (1999) study and the study presented here, the GAO sought to control for human capital characteristics "commonly used to estimate adjusted pay differences" (U.S. General Accountability Office 2010,3). The results showed that in 2007, full-time female managers in the leisure and hospitality sector earned approximately 80 percent of that of comparable male managers. Furthermore, this percentage had not changed significantly since 2000 , with female managers earning 79 to 80 percent of the amount earned by males in most years between 2000 and 2007 .

\section{Hypotheses}

Despite the weight of evidence, it is possible that the wage gap found by Sparrowe and Iverson in the hospitality industry in 1989 had diminished in 2010. The first factor suggesting its elimination is the simple passage of time, because women have moved into more senior and higher paid positions in the industry, as documented by Catalyst (2013a). Research has also shown that women who work in organizations with a greater number of female managers earn higher wages than women with similar qualifications and job descriptions working in organizations with more male managers (Hultin and Szulkin 1999). Thus, the advancement of women into management and leadership positions may have had both direct (via higher paid positions for the managers) and indirect effects (via raising wages for more junior women) on women's relative wages.

Second, in the last decade, there have been a number of high-profile class action settlements relating to genderbased discrimination in wages and promotions in several other industries, including $\$ 72.5$ million paid by Boeing Co. to 17,000 women in 2005 ; $\$ 33$ million paid by Citigroup Smith Barney to 2,500 women in 2008; $\$ 175$ million paid by Novartis to 5,600 women in 2010 ; $\$ 32$ million paid by Wells Fargo to 3,000 women in 2011; and \$39 million paid by Bank of America/Merrill Lynch to 4,800 women in 2013 (www.bigclassaction.com). It is possible that awareness of these successful lawsuits may have induced hospitality organizations in the United States to work proactively to reduce the gender wage gap among their workforce. I also note again the substantial efforts over the last two decades to support and advance the careers of women within the hospitality sector. It is reasonable to expect that one benefit of these efforts has been to reduce or eliminate the exclusionary social closure practices that contribute to genderbased differences in wages.

Despite those favorable trends, all the studies I have presented above document the persistence of a significant gender-based wage gap both across industries in the United States and within the hospitality sector both internationally and among U.S. managers. Furthermore, while there has been some progress in advancing women into leadership positions within the hospitality industry, they are far from reaching parity. In 2012, women comprised only 14.4 percent of executive officers and 14.2 percent of corporate directors among Fortune 500 hospitality companies, compared with 52.4 percent of the industry workforce (Catalyst 2013a). Given this, I hypothesize that just as Sparrowe and Iverson (1999) found two decades ago, the 2010 data will show that a significant gender-based wage gap persists within the U.S. hospitality industry in general, as well as within the restaurant and hotel sectors specifically, and among industry managers. Specifically, the following hypotheses are offered:

Hypothesis 1: Females in the hospitality industry will earn less than males after controlling for the effects of human capital, the new home economics, and crowding, thus implying that social closure and sex discrimination continue to disadvantage women in the industry.

Hypothesis 2: Females in the food services sector of the hospitality industry will earn less than males after controlling for the effects of human capital, the new home economics, and crowding, thus implying that social closure and sex discrimination continue to disadvantage women in the industry.

Hypothesis 3: Females in the lodging and accommodations sector of the hospitality industry will earn less than males after controlling for the effects of human capital, the new home economics, and crowding, thus implying that social closure and sex discrimination continue to disadvantage women in the industry.

Hypothesis 4: Female managers in the hospitality industry will earn less than male managers after controlling for the effects of human capital and the new home economics, thus implying that social closure and sex discrimination continue to disadvantage women in the industry.

\section{Method}

My intent in this study was to replicate the methodology used by Sparrowe and Iverson (1999) to the extent possible. However, I had to adjust my procedure in some respects due to certain changes within the sample data set between 1989 and 2010. These changes were a shift from collecting data via 
the census long form to the American Community Survey (U.S. Census Bureau 2010), and a change in industry and occupation codes from the Standard Industrial Classification (SIC) to the North American Industry Classification System (NAICS). Presented in the section below is a description of the specific methods used as well as the way in which each of the changes in the data set were addressed.

\section{Sample}

Like Sparrowe and Iverson, this study drew upon a 1 percent sample of the U.S. population drawn from the Public Use Microdata Sample (PUMS), which is available online. The sample comprised people that participated in the 2010 American Community Survey, which the U.S. Census Bureau implemented in 2000 to replace the census long form. The ACS allows for continuous annual measurement of the U.S. population, and, with one exception, the survey questions and the population surveyed for the ACS are the same as for the census form. As such, the ACS allows for an accurate replication of the Sparrowe and Iverson study.

From the 1 percent sample of the U.S. population, I extracted a sample of 112,990 individuals working in the hospitality industry. To do this, a list of all NAICS occupation classifications included in the data was first examined to identify occupations that were clearly hospitality related such as hotel clerks and bartenders. This process began with the list of 43 occupations shown in the Sparrowe and Iverson (1999) article. However, as some occupational classifications changed from the SIC code system to the NAICS system, a degree of judgment was applied to translate their list into the current system. The records for all individuals working in such occupations as well as records for all individuals working in the NAICS industry code for Food Services and Drinking Places (NAICS 722) and Traveler Accommodation (NAICS 7211). Extracting records based on industry code allowed for the inclusion of individuals working within the hospitality industry but in occupations that are more general in nature (such as mechanics, janitors, and salespeople). These two extractions resulted in a total of 50 occupations (presented in Exhibit 1) represented by employees working in the hospitality industry.

\section{Operationalization of Variables for Hypotheses Testing}

Given the goal of replicating and updating the Sparrowe and Iverson (1999) study, I created variables using the same methods they used, with one exception, as described below.

Income. Individual income was based on a single value in the PUMS data set that includes wages, salaries, commissions, cash bonuses, tips, and other income received from an employer during the preceding twelve-month period.
This income variable does not include reimbursements for business expenses, self-employed income, or other types of nonearned income such as public assistance, child-support, social security, or investment income. Just as was the case in Sparrowe and Iverson's (1989) data, the distribution of the variable for income differed significantly from normality. Therefore, it was transformed to the natural logarithm.

Human capital. The human capital variable was operationalized using each individual's level of educational attainment, as in the PUMS data set. Following Sparrowe and Iverson, the sample was divided into two groups by creating a dummy variable indicating whether or not the individual held a bachelor's degree $(1=y e s, 2=n o)$.

New home economics. To control for the new home economics explanation of pay variation, a variable was included to indicate the number of hours each individual worked in the preceding twelve months. Although Sparrowe and Iverson were able to draw this directly from the census data, the PUMS data set does not give this statistic. Instead, this is calculated from a set of ranges of the number of weeks worked in the PUMS data set, ${ }^{1}$ together with the average number of hours worked per week during the preceding twelve months. To calculate the variable for hours worked in the preceding twelve months, the midpoint of each indicated range of weeks worked per year was multiplied by the average number of hours worked per week. Once again, the variable for hours worked differed significantly from normality, and it also was transformed to the natural logarithm.

Occupational overcrowding and sex composition. To address the possibility that "female" jobs are lower-paid (Bergmann 1974), I calculated the proportion of women within each occupation (shown in Exhibit 1) and within each subsector of the hospitality industry, and then controlled for this proportion in each of the hypothesis tests.

Social closure (implied sex discrimination). Finally, I tested for outright pay discrimination, as expressed in social closure theory (Murphy 1988; Weber 1978). This is the key question to be answered in this study. To test this, each individual was coded as a man (coded as 1) or a woman (coded as 2 ), and then a series of ordinary least squares regression analyses was conducted, with income as the dependent variable, and gender, educational attainment, annual hours worked, and occupational crowding as the independent variables.

\section{Results}

All four hypotheses were supported, and the most likely explanation for the pay differentials seen in the data is outright discrimination. As a starting point, Exhibit 1 presents 
Exhibit 1:

Income by Industry, Sector and Occupation, and Gender in the Hospitality Industry for 2010.

\begin{tabular}{|c|c|c|c|c|c|}
\hline Occupation & $\begin{array}{l}\text { Employees } \\
\qquad(N)\end{array}$ & $\begin{array}{l}\text { Percentage of } \\
\text { Women }\end{array}$ & $\begin{array}{l}\text { Mean Income } \\
\text { Male (\$) }\end{array}$ & $\begin{array}{l}\text { Mean Income } \\
\text { Female }(\$)\end{array}$ & $\begin{array}{l}\text { Female's Relative } \\
\text { Mean Income (\%) }\end{array}$ \\
\hline Accountants and other financial specialists & 225 & 67.1 & 50,815 & 39,400 & 77.54 \\
\hline Aircraft pilots and flight engineers & $|, 63|$ & 4.7 & 96,154 & 69,166 & 71.93 \\
\hline Attendants & 3,044 & 41.0 & 8,584 & 9,746 & 113.55 \\
\hline Bartenders & 3,796 & 59.7 & 20,822 & 15,136 & 72.69 \\
\hline Bellhops & 248 & 27.4 & 23,122 & 21,426 & 92.67 \\
\hline $\begin{array}{l}\text { Bookkeepers, gaming cage Workers and other } \\
\text { financial clerks }\end{array}$ & 400 & 65.0 & 24,207 & 20,446 & 84.46 \\
\hline Cashiers & 152 & 77.6 & 31,106 & 17,655 & 56.76 \\
\hline Chief executives and legislators & 26 & 26.9 & 182,368 & 124,143 & 68.07 \\
\hline $\begin{array}{l}\text { Computer scientists, engineers and related } \\
\text { occupations }\end{array}$ & 61 & 13.1 & 58,796 & 77,775 & 132.28 \\
\hline Cooks and bakers & 22,181 & 45.6 & 13,983 & $|2,68|$ & 90.69 \\
\hline Counter help & 2,851 & 65.9 & 6,357 & 5,819 & 91.55 \\
\hline Customer service Reps & 236 & 57.2 & 22,254 & $|8,27|$ & 82.10 \\
\hline Entertainers, performers and related occupations & 67 & 55.2 & 37,870 & 19,909 & 52.57 \\
\hline Flight attendants & 963 & 80.0 & 45,469 & 35,893 & 78.94 \\
\hline Gaming services workers & 1,106 & 48.4 & 33,720 & 28,103 & 83.34 \\
\hline General office & 214 & 64.0 & 29,326 & 21,182 & 72.23 \\
\hline Groundskeepers & 108 & 13.0 & 16,047 & 11,902 & 74.17 \\
\hline Guides & 587 & 48.9 & 14,399 & 10,327 & 71.72 \\
\hline Hosts and hostesses & 3,154 & 87.6 & 7,390 & 6,401 & 86.62 \\
\hline Hotel clerks & 1,444 & 70.4 & $|7,42|$ & 14,747 & 84.65 \\
\hline Housekeepers & 3,186 & 88.7 & 16,823 & 13,438 & 79.88 \\
\hline Janitors & 640 & 17.5 & 19,198 & 14,626 & 76.18 \\
\hline Kitchen preparation workers & 12,197 & 61.9 & $|0,27|$ & 10,372 & 100.98 \\
\hline Laundry workers & 230 & 77.8 & 17,094 & 14,136 & 82.70 \\
\hline Managers: All others & 370 & 36.8 & 73,662 & 46,166 & 62.67 \\
\hline Managers: Lodging and food service & 9,434 & 48.5 & 47,481 & 31,084 & 65.47 \\
\hline Managers: Marketing and PR & 183 & 71.6 & 58,427 & 47,273 & 80.91 \\
\hline Managers: Personnel and labor & 64 & 70.3 & 74,363 & 59,296 & 79.74 \\
\hline Massage therapists and other health-related workers & 64 & 73.4 & 25,482 & 30,168 & 118.39 \\
\hline Mechanics & 269 & 1.9 & 25,467 & 39,000 & 153.14 \\
\hline Media and communications workers & 49 & 28.6 & 23,357 & 51,467 & 220.35 \\
\hline Miscellaneous food and beverage & 6,971 & 36.3 & 8,706 & 8,991 & 103.26 \\
\hline Miscellaneous Personal Services & 150 & 53.3 & 27,719 & 22,844 & 82.41 \\
\hline Miscellaneous supervisors and professional staff & 153 & 51.0 & 49,494 & 48,041 & 97.06 \\
\hline Miscellaneous laborers & 300 & 14.3 & 31,224 & 17,692 & 56.66 \\
\hline Motor vehicle drivers & 97 & 10.3 & 17,075 & $|4,65|$ & 85.80 \\
\hline Personnel, training and teachers & 62 & 79.0 & 40,185 & 40,799 & 101.53 \\
\hline Receptionists & 125 & 87.2 & $|3,13|$ & 13,582 & 103.44 \\
\hline Reservation and ticket agents & $|, 20|$ & 65.3 & 40,245 & 30,203 & 75.05 \\
\hline Salespersons & 134 & 76.1 & 45,260 & 28,928 & 63.91 \\
\hline Secretaries & 138 & 94.9 & 23,986 & 24,960 & 104.06 \\
\hline Security and safety workers & 355 & 14.1 & 20,726 & 17,228 & 83.12 \\
\hline Supervisory: Food service Occupations & 8,200 & 46.7 & 30,576 & $21,67 \mid$ & 70.87 \\
\hline Supervisory: Gaming workers & 759 & 44.1 & 47,002 & 29,232 & 62.19 \\
\hline Supervisory: General office & 92 & 75.0 & 42,870 & 28,819 & 67.22 \\
\hline Supervisory: Housekeeping and groundkeeping & 301 & 84.1 & 33,660 & 20,999 & 62.38 \\
\hline Supervisory: Sales & 235 & 52.8 & 39,257 & 28,778 & 73.31 \\
\hline Transportation attendants & 349 & 60.2 & 29,516 & $|7,48|$ & 59.22 \\
\hline Travel agents & 676 & 80.5 & 35,558 & 29,844 & 83.93 \\
\hline Waiters, waitresses and other food servers & 23,512 & 73.3 & 14,225 & 11,264 & 79.19 \\
\hline All employees & 112,990 & 56.7 & 49,367 & 32,328 & 65.48 \\
\hline All managers & 10,077 & 48.61 & 17,970 & 12,668 & 70.50 \\
\hline All food service & 68,593 & 53.77 & 31,572 & 20,978 & 66.45 \\
\hline All accommodation & 14,172 & 59.09 & 22,558 & 14,876 & 65.94 \\
\hline
\end{tabular}


Exhibit 2:

Means, Standard Deviations, and Correlations ${ }^{\mathrm{a}}$ for Study Variables.

\begin{tabular}{|c|c|c|c|c|c|c|c|}
\hline & $M$ & $S D$ & $\begin{array}{l}\text { Income } \\
\text { (Log) }\end{array}$ & $\begin{array}{l}\text { Bachelor's } \\
\text { Degree }\end{array}$ & $\begin{array}{c}\text { Hours } \\
\text { Worked (Log) }\end{array}$ & $\begin{array}{l}\text { Proportion of Women } \\
\text { in the Occupation }\end{array}$ & Gender \\
\hline Income (log) & 9.1464 & 1.3093 & 1.000 & & & & \\
\hline Bachelor's degree $^{b}$ & 0.1151 & 0.3192 & $.219 * *$ & 1.000 & & & \\
\hline Hours worked (log) & 6.8850 & 1.0181 & $.826 * *$ & $.124 * *$ & 1.000 & & \\
\hline $\begin{array}{l}\text { Proportion of women in } \\
\text { the occupation }\end{array}$ & $0.567 \mid$ & 0.1683 & $-.156 * *$ & $-.076 * *$ & $-.108 * *$ & 1.000 & \\
\hline Gender $^{\mathrm{b}}$ & I.567| & 0.4955 & $-.091 * *$ & $-.058 * *$ & $-.057 * *$ & $.336 * *$ & 1.000 \\
\hline
\end{tabular}

a. Statistics are for the entire sample $(N=112,990)$.

b. No bachelor's degree $=0$, bachelor's degree $=\mathrm{I}$. Male $=\mathrm{I}$, Female $=2$.

$* * p<.001$.

descriptive statistics on the overall sample of 112,990 hospitality employees by occupation, as well as on the samples of 68,593 food service employees; 14,172 accommodation employees; and 10,077 hospitality managers (includes all NAICS occupation codes with the word "manager" in the label, as well as the code for "Chief Executives and Legislators" [1110XX]). Women constituted 56.7 percent of the total sample and earned on average 65.9 percent of wages paid to men (average for women, $\$ 14,876$; for men, $\$ 22,558)$. On average, women comprise 53.9 percent of each occupation. ${ }^{2}$ Approximately 11.5 percent of employees in the sample held bachelor's degrees $(9.9 \%$ of females vs. $13.7 \%$ of males), and worked a mean of 1,370 hours per year (1,280 for females vs. 1,476 for males). By comparison, in 1989, the hospitality sector was 61.9 percent female, and approximately 6 percent of employees held bachelor's degrees; thus, over the last two decades, the industry has become somewhat more gender balanced overall, as well as slightly better educated.

Exhibit 2 presents descriptive statistics and correlations for each variable. As can be seen by the zero-order correlations, consistent with Sparrowe and Iverson's (1999) findings, the 2010 data show that working more hours and holding a bachelor's degree are associated with earning more income, while being female or working in an occupation with a higher proportion of females is associated with earning less income.

To test the hypotheses, multiple regression analyses were conducted, using the natural logarithm of earned income as the dependent variable and gender as the primary independent variable. For Hypotheses 1, 2, and 3, variables for education, hours worked, and the proportion of females in each occupation were included to account for human capital, new home economics, and crowding explanations of gender-based differences in earned income. To test Hypothesis 4, variables for education and hours worked were included, but there was no need to account for crowding as the analysis only included managers. The results are presented in Exhibit 3.
All four hypotheses were supported, as I explain here. As shown in column 1 of Exhibit 3, after controlling for the effects of education, hours worked, and crowding, gender was a significant $(B=.055, p<.001)$ predictor of earned income for the hospitality industry, thus supporting Hypothesis 1 . All four independent variables were significant $(p<.001)$ predictors of income, accounting in aggregate for 70.0 percent of the total variance. Exhibit 3 shows the results for the tests for gender effects on income within the food services sector (column 2) and accommodations sector (column 3). In both cases, after controlling for education, hours worked, and crowding, gender was once again a significant predictor of income (food services, $B=.058$; accommodations, $B=.133$; both $p<.001$ ). Furthermore, just as was found for the entire hospitality industry, all of the independent variables were significant predictors of income $(p<.001)$, accounting in aggregate for 70.7 percent of the variance in income in food service and 65.6 percent in accommodations. Hypothesis 4 was also supported, with the results indicating that gender was a significant $(B=$ $.422 ; p<.001)$ predictor of income for managers in the hospitality industry, after controlling for education and hours worked. In aggregate, the three independent variables accounted for 42.2 percent of the total variance.

A comparison of the betas $(B)$ for the gender variable in each test shows that gender had the greatest (negative) effect on income for managers, followed by employees in lodging and then employees in restaurants. The gender effect on income was also seen across the hospitality industry as a whole.

Using the data in this analysis, it is possible to develop monetary estimates of the cost of being a woman working in the hospitality industry (see Exhibit 4). As shown, for the hospitality industry as a whole, after controlling for the effects of education, hours worked, and crowding, being a woman was associated with a loss of income of $\$ 620$, relative to a mean income of $\$ 11,271$ per year. For the food service sector, being a woman cost $\$ 542$ relative to a mean annual income of $\$ 9,339$, and for the lodging and accommodations 
Exhibit 3:

Gender Differences in Income ${ }^{a}$ in the Hospitality Industry.

\begin{tabular}{|c|c|c|c|c|c|c|c|c|}
\hline \multirow[b]{3}{*}{ Independent Variable } & \multirow{2}{*}{\multicolumn{2}{|c|}{$\begin{array}{l}\text { Entire Sample } \\
\text { (Hypothesis I) }\end{array}$}} & \multirow{2}{*}{\multicolumn{2}{|c|}{$\begin{array}{c}\text { Food Services Sector } \\
\text { (Hypothesis } 2)\end{array}$}} & \multirow{2}{*}{\multicolumn{2}{|c|}{$\begin{array}{c}\text { Accommodation Sector } \\
\text { (Hypothesis } 3)\end{array}$}} & \multirow{2}{*}{\multicolumn{2}{|c|}{$\begin{array}{l}\text { Managers Only } \\
\text { (Hypothesis 4) }\end{array}$}} \\
\hline & & & & & & & & \\
\hline & $B$ & $S E$ & B & SE & B & $S E$ & B & $S E$ \\
\hline Intercept & $2.179 * *$ & 0.018 & $2.136 * *$ & 0.023 & $2.083 * *$ & 0.055 & $2.933 * *$ & 0.092 \\
\hline Bachelor's degree & $0.469 * *$ & 0.007 & $0.377 * *$ & 0.009 & $0.400 * *$ & 0.015 & $0.353^{* *}$ & 0.017 \\
\hline Hours worked (log) & $1.035^{* *}$ & 0.002 & $1.016 * *$ & 0.003 & $1.061 * *$ & 0.007 & $0.94 I * *$ & 0.012 \\
\hline $\begin{array}{l}\text { Proportion of women in } \\
\text { occupation }\end{array}$ & $-0.415^{* *}$ & 0.014 & $-0.25 \mathrm{I} * *$ & 0.020 & $-0.302 * *$ & 0.027 & NA & \\
\hline Gender & $0.055^{* *}$ & 0.005 & $0.058 * *$ & 0.006 & $0.133 * *$ & 0.013 & $0.218^{* * *}$ & 0.015 \\
\hline Adjusted $R^{2}$ & 0.700 & & 0.707 & & 0.656 & & 0.422 & \\
\hline F statistic & & & & & & & 2,4 & \\
\hline$N$ & $1 \mid 2,990$ & & 68,593 & & $|4| 7 \mid$, & & 10,076 & \\
\hline
\end{tabular}

a. Dependent variable is the log of income.

$* * p<.001$.

Exhibit 4:

Effects of Education, Work Hours, Proportional Representation of Women, and Gender on Income ${ }^{a}$.

\begin{tabular}{lcccc}
\hline & Entire Sample & Food Services Sector & Accommodation Sector & Managers \\
\hline Mean income & $11,27 I$ & 9,339 & 17,783 & 30,577 \\
Value of a bachelor's degree & 5,337 & 3,540 & 7,161 & 10,819 \\
Value of I SD more hours worked in 2010 & 28,406 & 24,440 & 33,673 & 36,084 \\
Cost of I SD greater proportion of & $-1,569$ & -787 & $-1,823$ \\
$\quad$ women in occupation & -620 & -542 & $-2,368$ & $-6,617$ \\
Cost of being a woman & & & \\
\hline
\end{tabular}

a. Data reflect income in 2010 .

sector, it cost $\$ 2,368$ compared with a mean income of $\$ 17,783$. Finally, for managers, after controlling for education and hours worked, being a woman cost $\$ 6,617$ compared with a mean annual income of $\$ 30,577$. Based on a comparison of the cost of being a woman to the mean income in each category, it appears that the penalties of being a woman are most severe among managers $(21.6 \%)$.

\section{Discussion and Implications}

These results provide strong evidence that there remains a significant difference in the income of women and men working in the hospitality industry. As Sparrowe and Iverson (1999) found in their analysis of 1989 data, the variables accounting for common explanations of the pay differences (i.e., human capital differences, the new home economics, and crowding) only partially explained gender differences in income. Data from both studies suggest sex discrimination in wages within the hospitality industry, with the unexplained wage gap for managers still the largest in percentage terms.
The 2010 data do indicate a slight narrowing of the gap, although the differences in data collection between the 1989 data and the 2010 study make a direct comparison impossible. Nevertheless, if one simply compares the cost of being a woman relative to the mean income for each sector in 2010 versus 1989, it appears that while the gap has narrowed across all of the groups considered, the least progress has been made among managers. In 1989, the ratio of lost income associated with being a woman to mean wage for managers was 27.4 percent, while in 2010, it was still a remarkable 21.6 percent. For the entire industry, the ratios were 10.7 percent in 1989 versus 5.3 percent in 2010, while for food service jobs, the ratios were 14.9 percent in 1989 versus 5.8 percent in 2010, and for lodging it was 15.0 percent in 1989 versus 13.3 percent in 2010. This lack of progress among managers is particularly discouraging, given that management positions are the most highly paid ones, and that it is these individuals who represent the pipeline for the executive ranks and thus will decide the future of the industry. 


\section{Managerial Implications}

Despite a substantial and increasing amount of discussion and debate over the last two decades about the advancement of women in the workforce, not to mention numerous industry initiatives and some apparent progress in narrowing the wage gap, it is clear that women still experience considerable wage discrimination in the U.S. hospitality sector. Even if one sets aside considerations of fairness and morality, the implications of this knowledge are significant. With women now making up well over 50 percent of college, master's, and doctoral graduates (Catalyst 2013b), as well as a growing percentage of graduates of hospitality programs (Sigala and Baum 2003), the industry will increasingly look to the female talent pool to fill positions at all levels and, most critically, to fill leadership positions. However, if the industry persists in systematically paying lower wages to its female employees - and in particular, its female managers - women may be discouraged from entering the industry (or staying, once they discover the pay situation). Several industries offer greater pay equity, including public administration, education services, information and communications, manufacturing, and wholesale trade (U.S. General Accountability Office 2010).

Furthermore, the industry could expect to see higher turnover among women, as several studies have shown that fair compensation is an important element contributing to career commitment among current students and graduates of hospitality programs, as well as other individuals considering work in the industry (Boles, Ross, and Johnson 1995; Chuang and Dellmann-Jenkins 2010; Knutson 1989; Walsh and Taylor 2007). Numerous studies have documented the damage caused by employees' voluntary turnover (Hinkin and Tracey 2000; Nishii 2013; Simons and Hinkin 2001; Tracey and Hinkin 2008), as well as ways to reduce turnover through adopting best practices in human resources (Hinkin, Holtom, and Liu 2012; Hinkin and Tracey 2010). Addressing the gender wage gap may be another means by which industry organizations can reduce costly turnover, particularly among women.

Equally damaging, wage inequality may prevent the best people from the industry talent pool from rising to the top. How might this happen? First, if women are paid less than men despite comparable performance, they may be perceived as somehow less competent by outside evaluators and therefore promoted more slowly. Second, faced with lower pay and fewer opportunities for advancement, women may rationally conclude not to invest as much time and effort in their careers as they otherwise might have (Blau and Kahn 2007), thus creating a self-fulfilling prophecy of women stuck in middle management or opting out of the industry or workforce entirely.

A further outcome of failing to reward female talent is that the industry may be missing out on the substantial organizational benefits that can be garnered through having a diverse employee base. Multiple studies have shown that gender diversity is associated with economic benefits such as more customers, increased sales revenue, greater profits, and higher stock performance, as well as more creativity, a better understanding of customers and markets, and a higher quality of products and services (Catalyst 2004; Desvaux, Devillard-Hoellinger, and Meaney 2008; Dezsö and Ross 2012; Herring 2009; Nielsen and Huse 2010). In particular, these benefits are achieved by organizations that simultaneously employ a gender diverse workforce and create a climate that encourages inclusion, as such a climate reduces the relationship and task conflicts associated with diversity, thus allowing just the benefits to shine through. Needless to say, equal pay and promotion policies are essential for creating a climate of inclusion (Kaplan, Wiley, and Maertz 2011; Nishii 2013). Thus, it is likely that gender-based wage inequality not only contributes to a lower level of representation of women employees and leaders but also decreases the likelihood of accruing the substantial benefits that whatever gender diversity remains may offer.

Finally, engaging in systematic sex-based wage discrimination, whether intentional or not, exposes hospitality organizations to significant legal claims under U.S. law. While there have not been any large public awards or settlements in the hospitality industry to date, I already noted the large settlements in other sectors. Moreover, recent data from the U.S. Equal Employment Opportunity Commission (EEOC; 2012) indicate that claims of sex-based discrimination hit a record high in 2012. Lawsuits filed in 2013 by the EEOC against Checkers and Extended Stay Resorts for gender wage discrimination further suggest the industry is not immune to such claims (U.S. Equal Opportunity Employment Commission 2013a, 2013b).

\section{Limitations and Future Research}

Given the goal of closely replicating and updating the study carried out by Sparrowe and Iverson (1999), my study is subject to some of the same methodological limitations as theirs. First, to draw a broadly based random sample, the study necessarily relied on the data gathered from the ACS, and thus was limited to the specific data variables included in the questionnaire. As such, differences in human capital were operationalized and controlled for by using each individual's level of educational attainment only, and not their experience. While educational level is a common variable used to estimate human capital, ideally, the research would have also included a variable accounting for differences in work experience. Although women are increasingly staying in the workforce even while caring for small children, they do, on average, take more and longer breaks from paid work than men, resulting in their having fewer overall years of work experience (Blau and Kahn 2007). In addition, there may be other legitimate factors contributing to the wage gap, such as job performance or job-specific skills, which 
were not accounted for in the regression model. As such, although the results presented here imply sex discrimination, just as Sparrowe and Iverson's (1999) results did, they cannot affirmatively prove it. Ideally, future research would use a data set that encompasses the strengths of the data used herein and addresses its weaknesses. In particular, such research should continue to be based on a true random population sample drawn from the universe of all U.S. hospitality occupations, while also accounting for a greater number of human capital variables and other factors that might legitimately contribute to the wage gap.

Second, like Sparrowe and Iverson (1999), the dependent variable in this study included income only from salaries and wages. Thus, these results do not capture any potential gender-based differences in the level of income earned from other sources, such as self-employment. Future research on the self-employed exclusively or research that captures income from a broader range of sources would help to elucidate the degree to which there are gender-based differences in these sources of income as well.

Third, while in most ways this study represents a fair replication of the Sparrowe and Iverson study, the change in the data source makes it impossible to statistically compare the results of the two. Future research that exactly replicates my study longitudinally would allow such comparisons and provide a useful barometer of the rate of progress (or lack thereof) that the hospitality industry is making in addressing the wage gap. This type of research is particularly important, given that this study suggests progress in narrowing the hospitality industry wage gap. One of the key tenets of driving organizational change is to first measure results and then to hold the organization and its leaders accountable to improving upon them. Statistically measuring the rate of progress toward completely closing the wage gap is a logical next step.

Finally, we need research that identifies the practices that have been most effective in driving progress toward the goal of wage equality. As I said above, the hospitality industry has implemented numerous initiatives to improve women's pay and status. We now need to know what else can be done. This study gives the U.S. hospitality industry an updated baseline of where it stands in relation to paying its female and male employees equitably. While there has been slow progress over the last two decades, there clearly is still work to be done. One can only hope that two decades from now, the gender wage gap is, in fact, eliminated, and that we are not still looking hopefully forward to the day that it is.

\section{Acknowledgments}

I thank Kate Walsh and Alyssa Goldman for their helpful comments on earlier drafts of this article.

\section{Declaration of Conflicting Interests}

The author(s) declared no potential conflicts of interest with respect to the research, authorship, or publication of this article.

\section{Funding}

The author(s) received no financial support for the research, authorship, or publication of this article.

\section{Notes}

1. The intervals were one to thirteen weeks, fourteen to twentysix weeks, twenty-seven to thirty-nine weeks, forty to fortyseven weeks, forty-eight to forty-nine weeks, and fifty to fifty-two weeks per year.

2. The average proportion of females in occupations differs from the overall proportion of women in the sample due to differences in the size of occupations.

\section{References}

Becker, Gary S. 1965. A theory of the allocation of time. The Economic Journal 75 (299): 493-517.

Becker, Gary S. 2009. Human capital: A theoretical and empirical analysis, with special reference to education. Chicago: University of Chicago Press.

Bergmann, Barbara R. 1974. Occupational segregation, wages and profits when employers discriminate by race or sex. Eastern Economic Journal 1 (2): 103-10.

Blau, Francine D., and Lawrence M. Kahn. 2007. The gender pay gap have women gone as far as they can? The Academy of Management Perspectives 21 (1): 7-23.

Blau, Francine D., and Lawrence M. Kahn. 2006. The US gender pay gap in the 1990s: Slowing convergence. Industrial \& Labor Relations Review 60:45-66.

Boles, James S., Lawrence E. Ross, and Julie T. Johnson. 1995. Reducing employee turnover through the use of preemployment application demographics: An exploratory study. Journal of Hospitality \& Tourism Research 19 (2): 19-30.

Boone, Juliette, Tatiana Veller, Kristina Nikolaeva, Mark Keith, Keith Kefgen, and James Houran. 2013. Rethinking a glass ceiling in the hospitality industry. Cornell Hospitality Quarterly 54 (3): 230-39.

Boraas, Stephanie, and William M. Rodgers III. 2003. How does gender play a role in the earnings gap? An update. Monthly Labor Review 126:9-15.

Brownell, Judi. 1994. Women in hospitality management: General managers' perceptions of factors related to career development. International Journal of Hospitality Management 13 (2): 101-17.

Campos-Soria, Juan Antonio, Bienvenido Ortega-Aguaza, and Miguel Angel Ropero-Garcia. 2009. Gender segregation and wage difference in the hospitality industry. Tourism Economics 15 (4): 847-66.

Catalyst. 2004. The bottom line: Connecting corporate performance and gender diversity. New York: Catalyst.

Catalyst. 2013a. Catalyst pyramid: Women in U.S. accommodations. New York: Catalyst.

Catalyst. 2013b. Catalyst quick take: Women in U.S. management and labor force. New York: Catalyst.

Catalyst. 2013c. Catalyst quick take: Women's earnings and income. New York: Catalyst.

Chuang, Ning-Kuang, and Mary Dellmann-Jenkins. 2010. Career decision making and intention: A study of hospitality undergraduate students. Journal of Hospitality \& Tourism Research 34 (4): 512-30. 
Delfin, L. D., and J. Varejao. 2007. Employment, pay and discrimination in the tourism industry. Tourism Economics 13 (2): 225-40.

Desvaux, Georges, Sandrine Devillard-Hoellinger, and Mary C. Meaney. 2008. A business case for women. The McKinsey Quarterly 4:26-33.

Dezsö, Cristian L., and David Gaddis Ross. 2012. Does female representation in top management improve firm performance? A panel data investigation. Strategic Management Journal 33 (9): 1072-89.

England, Paula. 1992. Comparable worth. New York: Aldine de Gruyter.

England, Paula. 2010. The gender revolution uneven and stalled. Gender \& Society 24 (2): 149-66.

García-Pozo, Alejandro, Juan A. Campos-Soria, José L. SánchezOllero, and Macarena Marchante-Lara. 2012. The regional wage gap in the Spanish hospitality sector based on a gender perspective. International Journal of Hospitality Management 31 (1): 266-75.

Hegewisch, Ariane, Claudia Williams, and Angela Edwards. 2013. The gender wage gap: 2012. Washington, DC: The Institute for Women's Policy Research.

Herring, Cedric. 2009. Does diversity pay? Race, gender, and the business case for diversity. American Sociological Review 74 (2): 208-24.

Hinkin, Timothy R., Brooks Holtom, and Dong Liu. 2012. The contagion effect: Understanding the impact of changes in individual and work-unit satisfaction on hospitality industry turnover. Cornell Hospitality Reports 12 (9): 6-12.

Hinkin, Timothy R., and J. Bruce Tracey. 2000. The cost of turnover: Putting a price on the learning curve. Cornell Hotel and Restaurant Administration Quarterly 41 (3): 14-21.

Hinkin, Timothy R., and J. Bruce Tracey. 2010. What makes them so great? An analysis of human resources practices among Fortune's best companies to work for. Cornell Hospitality Quarterly 51 (2): 158-70.

Hultin, Mia, and Ryszard Szulkin. 1999. Wages and unequal access to organizational power: An empirical test of gender discrimination. Administrative Science Quarterly 44 (3): 453-72.

Kaplan, David M., Jack W. Wiley, and Carl P. Maertz. 2011. The role of calculative attachment in the relationship between diversity climate and retention. Human Resource Management 50 (2): 271-87.

Kilbourne, Barbara Stanek, George Farkas, Kurt Beron, Dorothea Weir, and Paula England. 1994. Returns to skill, compensating differentials, and gender bias: Effects of occupational characteristics on the wages of white women and men. American Journal of Sociology 100:689-719.

Knutson, Bonnie J. 1989. Expectations of hospitality juniors and seniors: Wave II. Journal of Hospitality \& Tourism Research 13 (3): 193-201.

Marchante, Andres J., Bienvenido Ortega, and Ricardo Pagan. 2005. Educational mismatch and wages in the hospitality sector. Tourism Economics 11 (1): 103-17.

Muñoz-Bullón, Fernando. 2009. The gap between male and female pay in the Spanish tourism industry. Tourism Management 30 (5): 638-49.

Murphy, R. 1988. Social closure: The theory of monopolization and exclusion. Oxford: Oxford University Press.
Nielsen, S., and M. Huse. 2010. The contribution of women on boards of directors: Going beyond the surface. Corporate Governance: An International Review 18 (2): 136-48.

Nishii, L. 2013. The benefits of climate for inclusion for gender-diverse groups. Academy of Management Journal 56 (6): 1754-74.

Sigala, Marianna, and Tom Baum. 2003. Trends and issues in tourism and hospitality higher education: Visioning the future. Tourism and Hospitality Research 4 (4): 367-76.

Simons, T., and Timothy R. Hinkin. 2001. The effect of employee turnover on hotel profits: A test across multiple hotels. Cornell Hotel and Restaurant Administration Quarterly 42 (4): 65-69.

Skalpe, Ole. 2007. The CEO gender pay gap in the tourism industryEvidence from Norway. Tourism Management 28 (3): 845-53.

Sparrowe, Raymond T., and Kathleen M. Iverson. 1999. Cracks in the glass ceiling? An empirical study of gender differences in income in the hospitality industry. Journal of Hospitality \& Tourism Research 23 (1): 4-20.

Thrane, Christer. 2008. Earnings differentiation in the tourism industry: Gender, human capital and socio-demographic effects. Tourism Management 29 (3): 514-24.

Tracey, Bruce J., and Timothy R. Hinkin. 2008. Contextual factors and cost profiles associated with employee turnover. Cornell Hospitality Quarterly 49 (1): 12-27.

Umbreit, W. T., and P. E. Diaz. 1994. Women in hospitality management: An exploratory study of major and occupation choice variables. Hospitality \& Tourism Educator 6 (4): 7-9.

U.S. Census Bureau. 2010. American Community Survey 1-Year estimates. Washington, DC.

U.S. Equal Opportunity Employment Commission. 2013a. EEOC sues checkers for pay discrimination. Washington, DC.

U.S. Equal Opportunity Employment Commission. 2013b. EEOC sues extended stay hotels for pay discrimination based on sex. Washington, DC.

U.S. Equal Opportunity Employment Commission. 2012. Sexbased charges: FY 1997-FY 2012. http://www.eeoc.gov/eeoc/ statistics/enforcement/sex.cfm.

U.S. General Accountability Office. 2010. Women in management: Analysis of selected data from the current population survey. Washington, DC: U.S. Government Printing Office.

Walsh, Kate, and Masako S. Taylor. 2007. Developing in-house careers and retaining management talent what hospitality professionals want from their jobs. Cornell Hotel and Restaurant Administration Quarterly 48 (2): 163-82.

Weber, Max. 1978. Economy and society: An outline of interpretive sociology. Oakland: University of California Press.

Woods, Robert H., and Raphael R. Kavanaugh. 1994. Gender discrimination and sexual harassment as experienced by hospitality-industry managers. The Cornell Hotel and Restaurant Administration Quarterly 35 (1): 16-21.

\section{Author Biography}

Susan S. Fleming, Ph.D. is a Senior Lecturer at the Cornell University School of Hotel Administration. Her research and teaching interests include the challenges facing women in leadership and entrepreneurial management and finance. Prior to her academic career, Fleming spent over a decade on Wall Street as a private equity investor and remains active in the business world via membership on the board of directors of multiple publicly-traded companies. 